\title{
Livestock production and livestock products in the Turkish republic of northern Cyprus (TRNC): a field study and literature review
}

\begin{abstract}
Agriculture's share of the GDP of the TRNC has diminished over time but the sector contributes to food security, provides employment and enhances livelihoods. Almost half of agricultural GDP derives from livestock. The TRNC suffers from lack of recognition as a de jure state and trade embargoes but exports livestock products (especially cheese and poultry meat) to Turkey and Middle East and Arab Gulf countries. Low input-low output small farm production systems predominate but some large intensive dairy cow and poultry enterprises exist. Cattle, sheep and goats produce milk and meat, poultry yield meat and eggs and a few donkeys perform farm support functions. Much livestock output is eaten fresh but there are well developed value added enterprises, especially for 'hellim' cheese and poultry meat. Diseases of international importance and zoonoses reduce potential output. Livestock in TRNC make major contributions to the national economy and to welfare but perform well below their potential. Were they to receive better support internally and were international embargoes to be lifted they would contribute even more.
\end{abstract}

Volume 5 Issue 5 - 2017

\author{
R Trevor Wilson \\ Bartridge Partners, UK \\ Correspondence: R Trevor Wilson, Bartridge Partners, \\ Bartridge House, Umberleigh, EX37 9AS, UK, \\ Email trevorbart@aol.com
}

Received: May 02, 2017 | Published: August 02, 2017

Keywords: dairy cattle, farm animal genetic resources, cheese, animal diseases, agricultural economy

Abbreviations: TRNC, turkish republic of northern cyprus; KKTC, kuzey kıbrıs türk cumhuriyeti; GDP, gross domestic product; PDO, protected designation of origin; BSE, bovine spongiform encephalopathy; TSE, transmissible spongiform encephalopathies; LSD, lumpy skin disease

\section{Introduction}

The Turkish Republic of Northern Cyprus (TRNC) (Turkish language denomination: Kuzey Kıbrıs Türk Cumhuriyeti (KKTC)) is a self-declared De facto state that occupies the northern third of the island of Cyprus. It is not effectively a De jure state and is recognized internationally only by the Republic of Turkey. The total human population of the TRNC in 2011 was 286,257 and was increasing at 1.95 percent per annum. Some 60 percent of the population lived in rural areas in that year worked in or was dependent on agriculture to some extent. Most people live in the west and centre of the country with the north eastern Karpaz Peninsula being sparsely populated.

The land area of the TRNC extends to $330,383,968$ ha or $3,303.8$ square kilometres $(2,465,552$ dunum $) .{ }^{1}$ Agricultural land covers $187,348.48$ hectares $(1,398,123$ dunum) or 56.71percent of the total land area of which about 7.5percent is irrigated. Grazing land occupies 16,369.04 hectares (122,157 dunum) or 4.95percent of the land area. ${ }^{1-3}$ Animal husbandry is a major contributor to agricultural Gross Domestic Product (GDP). It was valued at about 45.7percent of total agricultural output in 2009, an almost 2-fold increase from its 20percent contribution when first invaded by the Turkish armed forces in 1974 while the total agricultural contribution to total GDP

'The official measure of area in North Cyprus is the 'dunum', a unit inherited from the days of the Ottoman empire. A 'Government donum' (G.D.) is equal to 0.3306 acre or 0.134 hectare. ${ }^{3}$ Numbers in brackets in this paragraph are official G.D. areas which have been converted by the author to hectares. fell from 16.4percent to 5.1 percent. ${ }^{2}$ Agriculture, as other sectors of the economy, suffers from externally imposed economic and political embargoes $^{4-6}$ which have severe negative effects, especially on exports. $^{7}$

Cyprus has a Mediterranean climate with hot dry summers and warm rainy winters. More precisely, the "Spring" season covers themonths of April and May, "Summer" normally lasts from June to September with the hottestmonths being June-August, "Autumn" is the short period that is themonth of October and "Winter" lasts from November to March with the coldestmonths being DecemberFebruary. At Kyrenia on the northern coast average high temperatures in winter are $15^{\circ} \mathrm{C}$ and average lows are $5^{\circ} \mathrm{C}$. Summer high temperatures average $33^{\circ} \mathrm{C}$ whereas the average low is $18^{\circ} \mathrm{C}$ : daily highs of up to $40^{\circ}$ are not uncommon. Rainfall varies across the country in the range $300-500 \mathrm{~mm}$ per annum. November through to February have averagemonthly rainfall of $50-100 \mathrm{~mm}$ falling on 10 to 12days: there is very little rain in themonths of May to October.

In addition to the vagaries of the climate, issues of concern for agriculture are the limited allocation of finances by the government coupled to restrictions on international financial assistance resulting from the lack of recognition of the TRNC as a legitimate country by all nations other than Turkey. ${ }^{8}$ The European Union has provided some funding for some activities as part of a process of reconciliation between the TRNC and the Republic of Cyprus ${ }^{9,10}$ which De facto is the southern two-thirds of the island. The EU states that it is the only external organization providing assistance (technical and financial) to the Turkish community of Cyprus. The assistance, however, is tempered by the complex web of rules and regulations for which the EU is notorious. Thus, in April 2004 the Official Journal of the European Union noted that "For public and animal health reasons, Regulation (EC) No 866/2004 prohibits the movement of live 
animals and animal products across the line between those areas of the Republic of Cyprus in which the Government of the Republic of Cyprus does not exercise effective control, to areas in which it does". ${ }^{11}$ A modification to this instrument was promulgated in 2007 as "Commission Decision of 4 May 2007 lifting prohibitions on the movement of certain animal products on the island of Cyprus under Council Regulation (EC) No 866/2004 and laying down conditions for the movement of those products $(2007 / 330 / \mathrm{EC})$ - fresh fish and honey"12 but it was not to be a simple border crossing but one hedged about with a plethora of restriction and reams of paper work.

Inadequate financial allocations by government are compounded by limited numbers of trained professionals in the public sector support services. The farming community in large part can be characterized as deficient in pertinent technical skills, that makes inadequate use of appropriate inputs and is poorly informed of market opportunities. In spite of agriculture's problems, however, the national agricultural sector is the major contributor of food to the people and the principal source of monies earned from exports which are primarily to Turkey but also to Middle East and Gulf States. In 2013, for example, 32.4 percent by value of exports were raw agricultural products with processed agricultural products contributing 50.8percent to exports: livestock products-especially processed dairy items and poultry meatare important constituents of exported goods. This paper reviews the livestock sector of the TRNC with respect to production systems, the presence and numbers of farm animal species, their production of food for human consumption and their disease problems. It is hoped that the paper will provide a background and make a contribution to the future development of the livestock industry.

\section{Materials and methods}

This paper is based on visits to farms and discussions with farmers and on objective observations of livestock operations during November 2015. The information thus obtained is supplemented with a thorough review of the limited and widely scattered literature relative to farm animal genetic resources and domestic animal husbandry in the TRNC.

\section{Production systems}

Livestock holdings are almost universally privately owned. Most enterprises are small scale and many are managed on a part-time basis and in association with crop production. Facilities for housing, feeding, control and management of stock are generally rudimentary. Hygiene is generally of a poor standard, ${ }^{13}$ there is little attention to biosecurity (except on some specialized large scale poultry units) and there is inadequate provision of and expensive animal health services.

Livestock feed is usually in short supply and much, especially for dairy production, is imported. Crop residues (cereal straws and haulms of pulses grown for human consumption) provide some of the fibre needed for maintenance and production. Crop by-products (bran from milling operations, legume pods and such items as marc from wine-making and date pits) provide limited feed. Feed is garnered by animals and gathered by owners from the sparse rangelands and from natural shrub and forest vegetation. About 11,426.31hectares (85,271dunum) or 6.10 percent of agricultural land are cultivated to legumes for fodder: total production is 6,835tonnes of which common vetch (Vicia sativa) provides 4,473tonnes, lucerne (Medicago sativa) 2,026 tonnes and grass pea (Lathyrus sativa) 336tonnes. ${ }^{3}$

The use of tractors for land and seedbed preparation, fodder conservation, harvesting and threshing has eliminated the need for animal power for draft and transport. Milk is now a sought-after food in the human diet. There is thus little use for native types but a greater need for dairy cattle. Holstein-Friesians now dominate the cattle industry. Herds of 50 head are not uncommon and there are some larger units. Such herds are mainly managed on a zero-grazing principle with total or almost total confinement in yards that serve for exercise and rest and for milking (Figure 1). Hand milking has been superseded by a mechanized bucket system whose power is a mobile electric generator (or, if close enough to a power line, from the grid). It is claimed that in the commercial sector there are 750 active cattle dairy farms which produce an annual 95,000tonnes of milk. Some 75 percent of this amount is produced by 160 large scale dairies that use modern technology including a cold chain. Artificial Insemination is nominally available from the public service but is unreliable and most farmers keep their own bull (Figure 1).

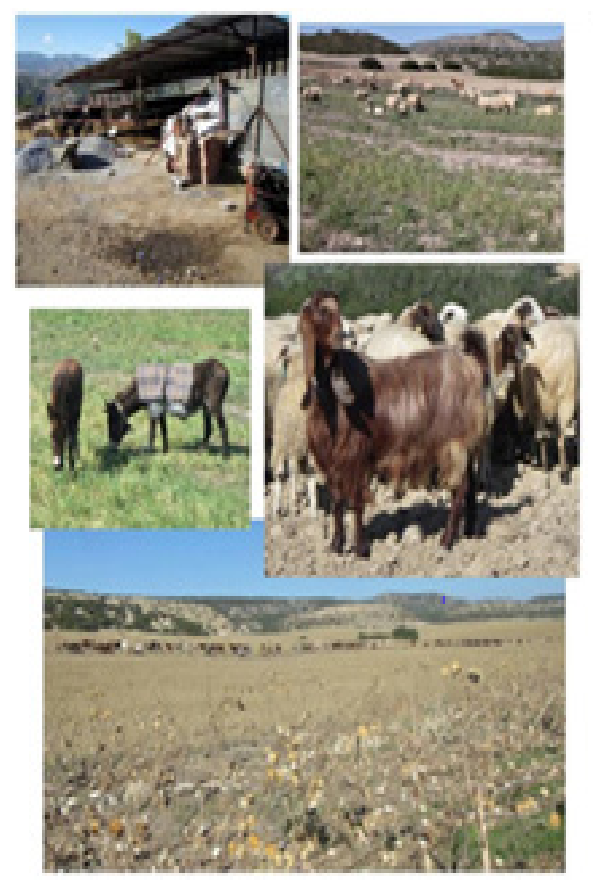

Figure I Systems and species in the Northern cyprus livestock sector (holstein-friesian cows in a confined dairy system; flock of mixed fat-tailed sheep on extensive grazing; a shepherd's donkey; a fine example of a damascus goat; village flock of local goats on the Karpaz Peninsula).

Sheep and goats are often kept together as a mixed flock. Flocks are small in the west and centre and often have limited access to open areas: some larger flocks that supply milk to cheese factories are permanently housed, intensively managed and milked by machine. In the northeastern Karpaz peninsula flocks are larger and usually herded out to feed on natural vegetation and arable stubbles. Some larger flocks belong to several owners who rotate their own labour for herding or hire a professional shepherd. Dogs are used to control and guard the stock and a donkey carries the shepherd's food and clothing. The basis of these two species is the indigenous type but there is often a ram or buck of a different (and generally superior) breed running with them. The result is that flocks present a very mixed appearance in terms of conformation and colour. It is estimated that 1,000 sheep and goat farms produce 10,000tonnes of milk for sale to local factories for processing into cheese. Consequent on males of both species being marketed at a young age of about fivemonths ${ }^{13}$ flocks are composed of 
about 70percent mature breeding female animals and younger females preparing to enter the breeding flock.

A few local poultry are kept by most rural households as a low input-low output activity which provides some household food and occasional small amounts of cash. Domestic fowl predominate in the species mix but turkeys, pigeons, geese, ducks and guinea fowl are kept by some households in small numbers. Many people still prefer the stronger flavour of local poultry flesh and the darker coloured yolks of these birds in comparison to the industrial products of broiler and battery birds. It has been estimated that 187 villages in the TRNC with 40-60 households in each keep an average of 23 birds in the range of 1-104 poultry per household ${ }^{14}$ there may thus be a total of about 215,000 birds in this system. About 40percent of households keep less than ten birds, 33percent have less than 20 birds and 8percent have less than 30 birds. Some 60percent of this village flock consists of laying birds (hens) whereas breeding males (cockerels, roosters) contributed just over 7 percent to total numbers.

In 2006 it was reported that five large industrial enterprises with their own feed mixing mills were operating in northern Cyprus and that 11 other large companies and 11 smaller ones were also in operation. The integrated operators had up to 140,000 broiler birds at any one time (with five production cycles per year), 35,000 birds were slaughtered every day and 110,000 table eggs were sold every day. ${ }^{14}$ Biosecurity measures and standards of management were deemed to be comparable to those in similar operations in the European Union. The very large farms keep their own parent stock for breeding replacements with a variety of the international hybrids being used.

\section{Livestock numbers and genetic resources}

Sheep are the most important ruminants, followed by goats and then cattle. Sheep numbers were in the range of 200,000 to 240,000 , goats in the range 50,000 to 60,000 and cattle 46,000 to 57,000 in the 5 year period 2007-2011 (Figure 2). The TRNC is a secular republic but the population is mostly Muslim which means there is limited production of pigs and consumption of pork. The poultry population comprises several species but the approximately 4.2million birds are overwhelmingly domestic fowl ("chicken"). A few donkeys are still used for support operations such as transport. Since the partition of the island into the Republic of Cyprus (south) and the TRNC many donkeys have been abandoned by their owners. An active and vociferous charity promotes conservation of these "wild" donkeys (Figure 2). ${ }^{15}$

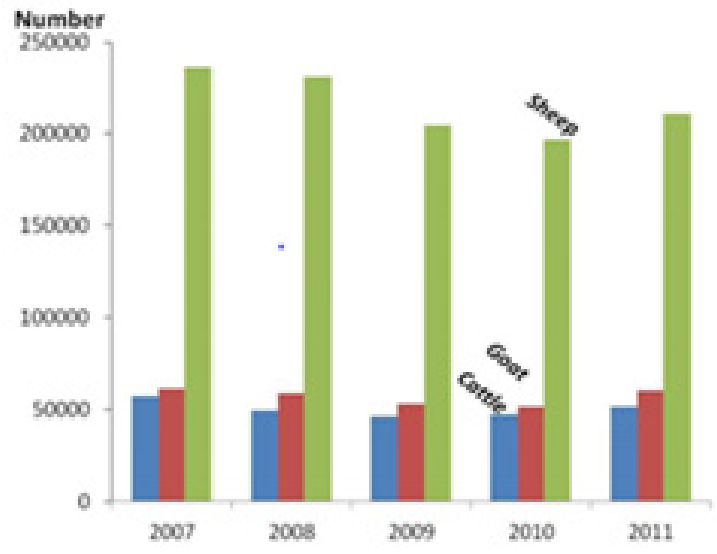

Figure 2 Ruminant livestock numbers in North Cyprus, 2007-20I I.
The genetic basis of Northen Cyprus for all species is an "indigenous" type. Cattle are of an ancient zebu -taurine (humpless) cross and were principally used for meat and the provision of draught power. The Cyprus Fat-tailed sheep is a triple purpose type producing milk, coarse wool and meat and is usually white with brown markings about the head. Cyprus goats are used for meat and milk and are usually multi-coloured although there is a white variant in mountainous areas. ${ }^{16}$ Over the last 100 years, however, but to a lesser extent since partition, the native types have been modified by the introduction of exotic genes: principally Holstein-Friesian for cattle, Awassi and Chios for sheep and Damascus for goats. ${ }^{17}$ Native fowl types-a few of which are still kept for cock fighting bouts-have increasingly been replaced with layer and broiler hybrids in medium to large scale commercial operations. The Cyprus donkey, as all such animals, is descended originally from African and Asian wild asses, but has been modified over time by introductions of Catalan blood.

\section{Performance and production}

Cattle: There does not appear to be any empirical data on individual performance for milk or meat for either the local breed or the Holstein Friesian. Information obtained from dairy farms using Holstein-Friesian under what can be described as a moderately well-managed system indicated peak daily yield of $17 \mathrm{~kg}$ of milk from two milkings over a 250day period which can probably be translated to a lactation yield of $3000-4000 \mathrm{~kg}$. Based on information from the Republic of Cyprus (south) better managed herds would probably have a lactation yield of $6000-7000 \mathrm{~kg}$.

Sheep: In a study covering 218 flocks in 48 villages in Northern Cyprus, fecundity (= number of lambs born per mated ewe) was 1.17 and infertility (+ ewes not lambing per ewe mated) was 8.81 percent. The number of lambs born at parturition was in the range 1.32 to 1.81 in different villages but averaged 1.57. Prior to weaning, however, 16.79 percent of these lambs died. Overall only 1.03 lambs per ewe mated were weaned. Lambs were weaned at 105.90days and then weighed $26.48 \mathrm{~kg}$. Ewes produced an average of $66.69 \mathrm{~kg}$ of milk per year in a milked period of 96.67 days at an average daily yield of $0.67 \mathrm{~kg}$. Animals were marketed at 147.11 days when they weighed $39.33 \mathrm{~kg}$. Mature ewes weighed $58.22 \mathrm{~kg}$ whereas mature rams weighed $84.96 \mathrm{~kg}$. Sheep reared in the mountains generally performed marginally worse than those reared in the lowland areas. ${ }^{13}$

Goats: In experiments performed at the Ercan State Farm in northern Cyprus research was focussed on milk production, reproduction and growth performances of Damascus goats. Birth rates, based on the number of does bred for 2001 and 2002 were 70.2percent and 80.5 percent, litter size, based on the number of kids born to the number of does giving birth, were 1.62 and 1.56 in the twoyears studied, kiddingpercentage, based on the number of kids born per 100 does put to the buck, were 114.3 percent and 125.9 per cent. Average daily milk yield was $1.90 \pm 0.042 \mathrm{~kg}$, lactation milk yield was $489.4 \pm 12.784 \mathrm{~kg}$ and lactation length was $254.7 \pm 2.359$ days. An average of $73.4 \pm 3.5 \mathrm{~kg}$ extra marketable milk was obtained when using a system of 30days suckling plus 30days milking and residual suckling whereby milk yield increased by 39 per cent to $259.0 \mathrm{~kg}$ in the first 90 days and by 16 per cent over the whole lactation period. The average daily weight gain of kids was $174.1 \pm 4.4 \mathrm{~g}$ for the system employing 30days suckling + 30days milking and residual suckling. ${ }^{18}$

In another experiment it was shown that milk yield, concentrate intake, hay intake, total feed intake, crude protein intake and 
metabolizable energy intake and live weight change were affected by feeding methods. Choice-feeding increased dry matter, energy and protein intake and milk yield and decreased live weight loss. Feeding methods had no significant effects on fat, protein or dry matter contents of milk but lactose and non-fat-solids contents increased according to concentrate intakes. ${ }^{19}$

Poultry: There is no information on the performance levels of backyard poultry but they would be expected to be low. In view of the evidence that biosecurity, hygiene and management levels of the large scale intensive units are comparable to those in the $\mathrm{EU}^{14}$ it could be expected that the egg production performance of layer units and the growth rates in broiler units would also be comparable to European levels.

Product outputs: Local production of milk, poultry meat, eggs and pork is adequate to supply local demand. Output of red meat, including veal, is not sufficient to meet internal consumption and is supplemented by imports. All three ruminant species are kept for the production of milk and meat. Cattle are by far the most important species for milk, providing almost 10 -fold the quantity produced by sheep and goats combined (Figure 3a). Cow milk is mainly consumed as fresh liquid milk or converted to yoghurt as the basis of the refreshing drink 'aryan'. Some cow milk is also used to make cheese and, somewhat controversially, in the manufacture of 'hellim' cheese. The greater proportion of the milk from sheep and goats is processed to cheese.

Poultry are the major meat source, with almost twice the output from cattle, sheep and goat combined (Figure 3b). The number of eggs produced rose from 23.62million in 2007 to 41.00million in 2011 . Minor products include wool with a yearly output of about 250tonnes and hides and skins. ${ }^{3}$ The manure produced by ruminants and poultry is used to a limited extent as a fertilizer for crop production.
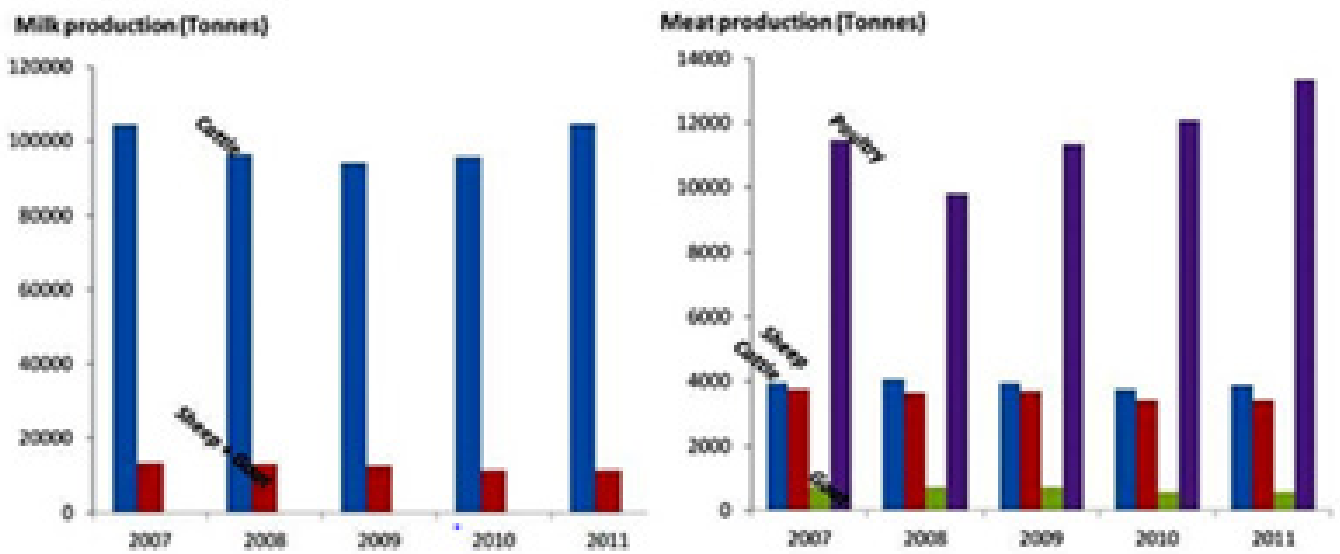

Figure 3 Milk and meat production by domestic livestock species in Northern Cyprus, 2007-20I I.

Exports deriving from the livestock industry are now confined to dairy products and poultry. In the past, however, live animals were exported as, for example, the 20,596 sheep and 11,104 goats, valued at TL1.86 billion (US\$ 3.15billion; exchange rate TL 1.00=US\$ 2.11 at that time), were exported to Arab countries in $1987 .{ }^{20}$ The total value exports from the TRNC in 2010 was US\$ 96,419,909: dairy product exports were valued at US\$25,826,381 or 26.8percent of the total whereas exports of poultry meat had a value of US $\$ 2,747,256$ equivalent to just 2.8 per cent of the total. In 2011 the value of exports had increased to US\$115,706,735 of which US\$26,915,239 or 23.3 per cent was from dairy products and US\$ $5,194,539$ or 4.5 per cent was from poultry meat.

Turkey is by far the single largest recipient of TRNC livestock product exports, taking 54.1percent of total exports in 2009 and 46.4percent of total exports in 2010: Lebanon and Jordan (and Syria before the current Civil War erupted) are other important markets for northen Cyprus exports as are the Gulf States. In addition to being the biggest outlet for exports, Turkey is also the biggest source of imports to northen Cyprus, accounting for as much as 70percent of all imports in 2010. The trade embargoes mean that goods exported from the TRNC cannot be exported directly to the countries of the European Union so they pass through Turkey but with consequential increased transaction costs. As the Republic of Cyprus is a member of the EU it cannot import goods from the TNRC but in what is clearly an ironic and inequitable situation export goods (and people and services) can cross the Green Line in the opposite direction from south to north. ${ }^{21}$
Adding value: Value added products are those whose worth has been increased by marketing, manufacturing or processing. Meat and milk, being perishable products with a short natural shelf life, lend themselves naturally to value added processes. In the TRNC both milk and meat are processed to various kinds of added value products (Figure 4) to be sold wholesale or retail on the local and export markets.

Milk is a highly perishable commodity but lends itself readily to value added processing. At a household level it can be converted to yoghurt, butter and cheese on a small scale. These products can be processed on an industrial scale and further products include condensed milk and milk powder. Yoghurt diluted with water and with salt added - known as 'aryan' in northern Cyprus - is a common and highly appreciated local beverage made at both household and industrial scales. Butter is a further value added product but without cold storage it does not have a long storage life. It is cheese, however, that is the most apt product for value added and for a long period of storage. Cheese derives largely from the protein in the milk and it takes about $10 \mathrm{~kg}$ of cow or goat milk to produce $1 \mathrm{~kg}$ of cheese but only $6 \mathrm{~kg}$ of the richer sheep milk to produce $1 \mathrm{~kg}$ of cheese. The monetary value of cheese is more than double, and often has an even higher multiple, than that of the primary product from which it is made. Cheese manufacture also has an additional advantage in that the liquid residue, known in English as 'whey' can be used (with the addition of about 5-10percent of whole milk) to produce a soft cheese which also has a reasonably long storage life: the Italian 'ricotta' is the best known of these whey cheeses. 


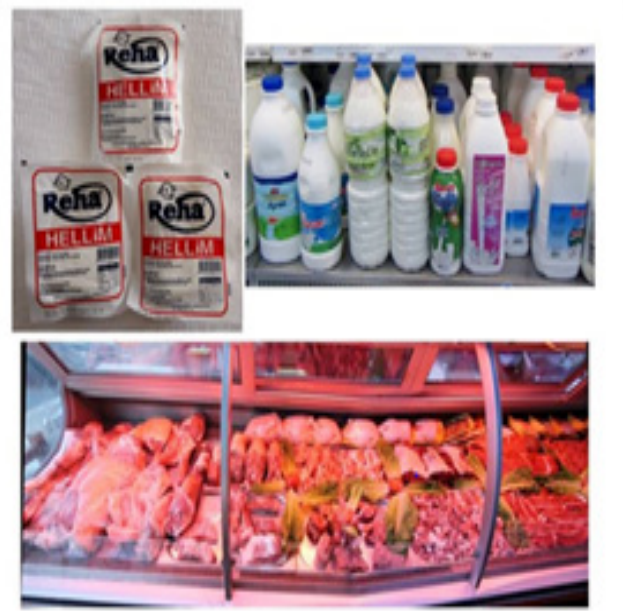

Figure 4 Value added milk and meat products of northern cyprus (hellim cheese aryan diluted yoghurt; fresh meat cuts of cattle, sheep, goat and poultry).

Among local cheeses, 'hellim' (the Turkish word for the more widely understood Greek 'haloumi') is the most important. It is still widely manufactured at the household level and in about ten modern factories which draw milk from small and larger producers to produce cheese mainly for export. As already indicated 'hellim' exports represent a quarter of total goods traded by the Turkish Cypriot community and some one in six (16 per cent) of Turkish Cypriots depend largely on 'hellim' production for their livelihoods.

An ancient cheese originally made from goat or sheep milk or a mixture of both (there were no cattle on the island then) much of this cheese variety is now made with or has cow milk included in the mix. There is considerable controversy over the inclusion of cow milk and how much of it can be included if the denomination 'hellim' is to be used. The designation 'hellim' was registered as a precise product in 2008 under the TRNC "Law on the Protection of Geographical Indications and Traditional Names of Products": Article 24 of this law and a Regulation issued under Article 38 are the pertinent legislation ensuring that the product is properly inspected and conforms to the legal description. Under its own laws, the Republic of Turkey gave a Protected Designation of origin (PDO) to northern Cyprus 'hellim' in 2009.

The implications of PDO are not, however confined to the island of Cyprus. On 17 July 2014 the Republic of Cyprus made an application to the EU for PDO status for the cheese under both the Greek 'haloumi' and Turkish 'hellim' names with the geographical area of production being the whole of the island ${ }^{2}$. The application was published in the Official Journal of the European Union on 2 July $2015^{22}$ for consultation and to provide the opportunity for objections to be made. By mid-April 2016 nine objections had been lodged from within Cyprus and across the world from manufacturers already using 'haloumi' as a (non-protected) brand name.

As already indicated the whey from cheese making can be used to produce additional value added products. In northen Cyprus 'anari' is made as a cylindrical shaped unripe white cheese of Ricotta

${ }^{2}$ The whole island is included in the application because the EU considers the total area to be the Republic of Cyprus with the northern "area outside Government control" being illegally occupied by Turkish armed forces. type. Other traditional and non-traditional cheeses made in northern Cyprus include 'kefalotyri' which is a hard, salty yellow cheese made from sheep or goat milk, 'beyaz peynir' (white cheese) made from unpasteurized goat milk and 'kasai' made mostly from cow milk.

Meat of all three ruminant species is preserved by smoking or sundrying or simply prepared as various fresh cuts. A traditional Cyprus meat product is 'samarella', which is made of pieces of goat meat that are salted and seasoned with dried oregano and then air-dried in the sun for approximately 10days. A similar product is 'apohtin' or 'apohti' also made of salted goat meat. Șeftali Kebab (Sheftali Kebap) is another traditional Cypriot meat product made of minced lamb shoulder or leg seasoned with finely chopped onion, parsley and salt that is encased in lamb intestine as a form of sausage. A further type of sausage is 'lukániko' usually made of pork flavoured with orange peel, fennel seed and various other dried herbs and seeds and often smoked for better preservation but this is not very popular among the Turkish Cypriot Muslim community (Mr Altaylor, Retail Butcher at Alsancak Kyrenia, pers. comm, 2015)

In addition to oven-ready whole chicken the industrial poultry industry produces several other value added products for both the local and export markets. These include breasts, thighs, drumsticks, wings, livers, giblets and gizzards. Some of these outputs achieve additional value by various treatments such as chicken shish kebab, chicken pieces in sauce and boned out legs and thighs.

Disease: It has been said that "Cyprus, being an island and with well organized veterinary services, is at a lower risk from animal diseases than many other countries. However the potential of disease threat exists and occasionally, in places with high density of animals per unit area, there are problems, especially with highly contagious diseases". ${ }^{23}$ The foregoing statements apply to the Republic of Cyprus but the situation could be similar in the TRNC. Certainly, a wide range of pathogenic diseases has been reported for northern Cyprus that affect ruminants and non-ruminants alike. Some of these diseases are so-called transboundary diseases of international concern and others are zoonoses, that is they are capable of being transmitted from animals to man.

In 1974-1975 some 78 British military personal at the Eastern Sovereign Base Area - which borders on northern Cyprus were diagnosed with Q fever. Pneumonia developed in 59percent of cases, 81percent of 31 patients tested had biochemical evidence of hepatitis although only one became clinically jaundiced and 4 percent suffered pericarditis. Investigation revealed an abortion epidemic involving 21 mixed flocks of sheep and goats in nearby areas with 11 of these flocks grazing in and around the Base Area. A serological survey of ten affected flocks indicated that abortions were due to infection with Coxiella burnetii, the causal organism of Q fever. The infection in soldiers was almost certainly from inhalation of dust from vegetation contaminated with rickettsial parturition products from the aborting flocks. A human serological survey identified several cases of subclinical Q fever in a susceptible military population and an asymptomatic epidemic in a largely immune local population. ${ }^{24}$ Q fever is mainly subclinical but is associated with late abortions, stillbirths, weak offspring, metritis and infertility in ruminants but sheep and goats are most affected and abortions are rare in dairy cows. Ticks are also important in transmitting the disease in ruminants and humans. In a recent study 22 (37percent) of a total of 59 randomly sampled abortion cases in ruminants were found to be caused by $C$. 
Burnetii with those from the border region between north and south Cyprus showing the highest incidence..$^{25} \mathrm{~A}$ somewhat earlier and larger study had also shown that the border region had the highest cumulative seroprevalance rates of $C$. Burnetii specific antibodies. ${ }^{26} \mathrm{Q}$ fever has been a public health problem in Cyprus for manyyears so control of $C$. Burnetii infection in ruminants is an important component of public health. Ticks on aborted animals and poor hygiene have been identified as the most important on-farm risk factors associated with C. Burnetii infections. ${ }^{26}$

Brucellosis is a disease that causes abortion in ruminants and is caused by the bacteria Brucella abortus in cattle and Brucella melitensis in sheep and goats. The disease is easily transmissible to humans in close contact with animals and causes a transient fever, hence a common English name of Undulant Fever and also Malta Fever. Brucella abortus was accidentally introduced to Cyprus (the island) in a consignment of dairy cattle imported from the United Kingdom in 1921 and persisted until a last case was reported in 1932. ${ }^{27}$ B. Melitensis was endemic in Cyprus before the 1970s but following a $15 y$ year eradication campaign the island was declared free from brucellosis. In 1997, however, the disease reappeared and a new brucellosis elimination campaign was reintroduced in the Republic of Cyprus. In northern Cyprus the incidence of animals giving positive results to serodiagnosis between 2000 and 2004 was from 0.34 to 1.19 percent on an annual basis, the results being obtained from very large samples ranging from 18,000 to 40,000 animals. ${ }^{28}$ The last positive case there was recorded, according to OIE data, in 2010. On 30 April 2013 following 13years of campaigns the Republic of Cyprus requested the European Commission to grant it Officially Free Member State Status from B. Melitensis. Following an evaluation and a favourable vote, on 5 December 2014, on the documentation submitted by Cyprus, the Member State was recognized as being officially free of brucellosis (B. Melitensis), the purpose of the Commission Implementing Decision being to amend Annex I to Decision 93/52/EEC accordingly. ${ }^{29}$ It should be noted that this freedom from infection covered the whole island based on the EU's recognition of the Republic as being the whole island with an illegally occupied part in the north. In early 2014, however, there was an outbreak of brucellosis amongst populations of livestock all over the TRNC which was rapidly developing as there was no money in the budget to fight it. The chairman of the Livestock Producers Union confirmed that the disease had been discovered on 60 farms and criticized the authorities for not controlling the disease. The official responsible for agriculture in TRNC noted that the cost of controlling the disease was very high and they had applied to the EU for money. ${ }^{30}$ It can probably be assumed that the causal organism was Brucella melitensis as the outbreak was in sheep and goats. A plan for the control and eradication of brucellosis in northern Cyprus to be implemented over fiveyears has been prepared. ${ }^{28}$

Scrapie is one of the group of diseases known as transmissible spongiform encephalopathies (TSE) that include bovine spongiform encephalopathy (BSE) and human Creutzfeldt-Jakob disease. ${ }^{31}$ It is a fatal disease in sheep and goats. There has always been a stigma attached to scrapie but in the past death of individual animals was the main measure of loss. Now, however, scrapie infection can limit international trade in live animals and livestock products. Affected farms and areas suffer losses due to decreased value of breeding stock and the need for eradication or control programmes. Following the BSE epidemic in the United Kingdom there is more pressure for producers and, if possible, countries to become scrapie free ${ }^{3}{ }^{31}$ Scrapie was first confirmed in sheep in Republic of Cyprus in $1985^{32}$ and this was followed by the first confirmed case in goats in $1986 .{ }^{33}$ Scrapie has been a problem on Cyprus ever since its first appearance. It was not, however, until 1998 that suspected cases of scrapie were noted but no tests were carried out. Classical scrapie was not confirmed for the first time in northern Cyprus until 2009 when four animals aged 2-3years in a flock of 200 were diagnosed positive: the whole flock was slaughtered and buried as a measure to eradicate the disease and in accordance with EU rules. ${ }^{34,35}$

Lumpy Skin Disease (LSD) is an insect borne virus disease that is widespread in Africa. The disease was reported in the Karpaz Peninsula in November 2014, having never been known in any part of the island previously. Immediate steps were taken to control the disease by slaughtering affected and in contact cattle. ${ }^{36}$ The Republic of Cyprus, whose agriculture minister said the disease had arrived from Turkey requested EU experts to come to the island to monitor the situation as "the Republic does not have any control over the north" and it "was a very important matter as it was the first time LSD had appeared on EU soil". ${ }^{37}$

An outbreak of Highly Pathogenic Avian Influenza virus (H5N1) in northern Cyprus was confirmed by the Community Reference Laboratory, Weybridge, UK on 29 January $2006 .{ }^{14}$ The outbreak was of an isolated nature and was contained by the measures implemented by the veterinary services. No source of infection was established and it was also difficult to understand that a disease of such an infectious nature remained an isolated incident. ${ }^{14}$

Newcastle disease is frequently reported from the southern Republic of Cyprus (see, for example, regular articles of The Poultry Site at http://www.thepoultrysite.com). An outbreak in the TRNC attributed to the disease crossing the border from the south was reported in June 2013. The Director of the north Cyprus Veterinary Department said that "hundreds of fowl have already been destroyed" but that the disease had not occurred in commercial establishments. ${ }^{38}$

Other diseases, including other zoonoses, are likely to be present in northern Cyprus but have not been recorded. Bovine tuberculosis, for example, was recorded in Cyprus for the first time in 1922 when it was introduced by imported dairy cattle from the UK. Over twoyears the disease had spread from the Government farm to many private dairy farms. Cattle of the local breed used as working animals were generally not affected ${ }^{4}{ }^{27}$ Anthrax was formerly one of the most serious diseases of sheep and goats in Cyprus and caused severe economic losses. It is considered to be eliminated ${ }^{39}$ but anthrax spores can live for manyyears undetected in soil and then break out again. An island-wide programme for control of hydatid disease/echinococcosis was initiated in 1971 but the programme was reportedly abandoned in the north after the 1974 Turkish invasion and it is said "a very high incidence of disease is reported in humans and livestock in the

${ }^{3}$ BSE is known colloquially as "Mad Cow Disease". A relevant example of the loss of value and negative effects of scrapie on international trade is when the author of this paper was employed by an international development bank in 1995 to assist Cyprus (which wanted to export sheep and goats) in negotiations with Jordan (which had need of sheep and goats and was receiving financing from the bank)) with regard to the transfer of animals: the negotiations failed due to the presence of scrapie in Cyprus (although the animals to be transferred were certified scrapie-free).

${ }^{4}$ This is an interesting observation as very few zebu cattle in Africa are infected with tuberculosis even when running with humpless and susceptible cattle. 
occupied areas". ${ }^{40}$ There do not appear, however, to be any published reports of hydatid disease in the TRNC but sporadic cases of hydatid cysts detected at slaughter in the south are "mostly considered to be due to the smuggling of animals from the occupied areas of the island" 39

\section{Discussion}

The livestock sector of the TRNC is of major importance to the national economy. It ensures a considerable flow of exports, adds to food security, provides gainful employment and contributes to improved livelihoods. Yet it is beset by problems due not only to the TRNC's international isolation but by limited internal funding and other forms of support. The sector's obvious strengths are offset by manifest weaknesses. Similarly the opportunities available to the sector are faced with an array of difficult threats (Table 1). The livestock sector of the Turkish Republic of Northern Cyprus is already a strong force for good for the country and its people. Concentrating on the strengths and opportunities and contesting the weaknesses and threats will go far towards the goal of the sector achieving its full potential.

Table I Swot analysis of the livestock sector in the Turkish Republic of Northern Cyprus

\begin{tabular}{|c|c|}
\hline Strengths & Weaknesses \\
\hline $\begin{array}{l}\text { Locally adapted animal } \\
\text { genetic resources }\end{array}$ & Insufficient trained technical personnel \\
\hline $\begin{array}{l}\text { Dairy production and } \\
\text { specialized added value } \\
\text { products }\end{array}$ & $\begin{array}{l}\text { Inadequate knowledge and skills of } \\
\text { producers }\end{array}$ \\
\hline Poultry production & Limited research \\
\hline $\begin{array}{l}\text { Modern processing } \\
\text { industries with good } \\
\text { facilities }\end{array}$ & Lack of funding \\
\hline Source of employment & Poor infrastructure \\
\hline Opportunities & Threats \\
\hline $\begin{array}{l}\text { Improve genetic basis of } \\
\text { production }\end{array}$ & $\begin{array}{l}\text { Lack of international recognition of } \\
\text { TRNC }\end{array}$ \\
\hline $\begin{array}{l}\text { Broader range of added } \\
\text { value products }\end{array}$ & Antagonism from Republic of Cyprus \\
\hline Greater quantity and & $\begin{array}{l}\text { Foreign product imports competing } \\
\text { with local items Competition from } \\
\text { other sectors for resources }\end{array}$ \\
\hline \multicolumn{2}{|c|}{ better quality of animal feeds } \\
\hline $\begin{array}{l}\text { Better organization of } \\
\text { farmers for marketing }\end{array}$ & $\begin{array}{l}\text { New and resurgence of old animal } \\
\text { diseases }\end{array}$ \\
\hline $\begin{array}{l}\text { Targeting of existing and } \\
\text { opening new markets }\end{array}$ & $\begin{array}{l}\text { Climate change and environmental } \\
\text { degradation }\end{array}$ \\
\hline known ar & ate technology \\
\hline
\end{tabular}

\section{Acknowledgements}

None.

\section{Conflict of interest}

Author declares that there is no conflict of interest.

\section{References}

1. Cakirdag S, Haydar E, Nalbantoglu N, et al. Agricultural Structure and Production 2009. Nicosia, TRNC: Statistic and Planning Division. Ministry of Agriculture and Natural Resources. Nicosia, Cyprus; 2010.

2. SPO. Economic and Social Indicators, Annual Statistics. North Cyprus: State Planning Organization, Follow up and Coordination Department, Nicosia, Cyprus; 2010

3. Statistical Yearbook 2011. Nicosia: Statistics and Research Department, State Planning Organization. Government of Northern, Nicosia, Cyprus: SARD; 2015.

4. Guryay E, Safakli OV, Tuzel B. The comparative analysis of agricultural sector productivity in North Cyprus and the European Union. Journal of Mediterranean University. 2003;18(1):51-61.

5. Katircioglu ST. Co-integration and causality between GDP, agriculture, industry and services growth in North Cyprus: evidence from time series data 1977-2002. Review of Social, Economic and Business Studies. 2006;5/6:173-187

6. Katircioglu ST. Causality between agriculture and economic growth in a small nation under political isolation: A case from North Cyprus. Emerald Group Publishing Limited; 2006;33:331-343.

7. Guncavdi O, Kucukcifci S. Economic growth under embargoes in North Cyprus: an input-output analysis. Turkey: Faculty of Management Istanbul Technical University; 2008:1-31 p.

8. Odeh AO. The impact of agriculture on the economic development of northern Cyprus. International Journal of Scientific Research in Information Systems and Engineering. 2015;1(1):1-9.

9. EC. Closer to the European Union. EU Assistance to the Turkish Cypriot Community. Nicosia, Cyprus; 2012.

10. EC. Report From the Commission to the Council and the European Parliament Seventh Annual Report 2012 on the implementation of Community assistance under Council regulation (EC) No 389/2006 of 27 February 2006 establishing an instrument of financial support for encouraging the economic development of the Turkish Cypriot community (Annex). Brussels: European Community. 2013.

11. EU. COUNCIL REGULATION (EC) No 866/2004 of 29 April 2004 on a regime under Article 2 of Protocol 10 to the Act of Accession. Official Journal of the European Union L 161 of 30 April 2004. 2004:1-4 p.

12. EU. COMMISSION DECISION of 4 May 2007. Official Journal of the European Union. 2007.

13. Taskin T, Kaymakci M, Kosum N, et al. The structure and productivity of sheep husbandry in Turkish republic of Northern Cyprus (NCTR). Pakistan Journal of Biological Sciences. 2006;9(12):2375-2377.

14. Lohr JE, Greiner M. Initial Assessment mission on Avian Influenza, 30 January-1 February 2006-Report. Brussels: Technical Assistance Information Exchange Instrument of the European Commission. 2006

15. FSD. Donkeys in Cyprus. Friends of the Cyprus Donkey, Vouni, Cyprus; 2016.

16. Mason IL. A world dictionary of livestock breeds, types, and vanities. 4th ed. Wallingford, UK. 1996 
17. Constantinou A. Ruminant livestock genetic resources in Cyprus. Animal Genetic Resources Information. 1985;4:1-8.

18. Güney O, Torun O, Özuyanık O, et al. Milk production, reproductive and growth performances of Damascus goats under northern Cyprus conditions. Small Ruminant Research. 2006;65:176-179.

19. Görgülü M, Güney, Torun $\mathrm{O}$, et al. An alternative feeding system for dairy goats: Effects of free-choice feeding on milk yield and milk composition of lactating suckling Damascus goats. Journal of Animal and Feed Sciences. 2003;12:33-44.

20. SPO. Statistical Yearbook, 1987. Nicosia, North Cyprus: State Planning Organization, Follow up and Coordination Department, Prime Ministry. 1988.

21. SPO. Turkish Republic of Northern Cyprus: Economy. Nicosia, North Cyprus: Economic Planning Department, State Planning Organization, Ministry of Economy and Energy, Republic of Northern Cyprus; 2012.

22. EU. Publication of an application pursuant to Article 50(2) (a) of Regulation (EU) No 1151/2012 of the European Parliament and of the Council on quality schemes for agricultural products and foodstuffs $(2015 / \mathrm{C}$ 246/12). Official Journal of the European Union. 2015

23. Papachristoforou P. Cyprus Country Report on the State of Farm Animal Genetic Resources: Contribution to the First Report on the State of the World Animal Genetic Resources. Nicosia: Ministry of Agriculture, Natural Resources and Environment. 2003.

24. Spicer AJ, Crowther RW, Vella EE, et al. Q fever and animal abortion in Cyprus. Trans R Soc Trop Med Hyg. 1977;71(1):16-20.

25. Cantas H, Muwonge A, Sareyyupoglu B, et al. Q fever abortions in ruminants and associated on-farm risk factors in northern Cyprus. BMC Veterinary Research. 2011;7:13.

26. Psaroulaki A, Hadjichristodoulou C, Loukaides F, et al. Epidemiological study of Q fever in humans, ruminant animals, and ticks in Cyprus using a geographical information system. Eur J Clin Microbiol Infect Dis. 2006;25(9):576-586.

27. Steele JH, Polydorou K, Orphanides A, et al. Zoonoses in Cyprus past and present including a comment on the public health. International Journal of Zoonoses. 1976;3:65-76.
28. Pasa D. Bovine brucellosis in the northern part of Cyprus, control and eradication plan. Powerpoint presentation. In: Proceedings of the Zoonotic Diseases Symposium. Lefkoşa, Cyprus; 2011:30-31.

29. EU. Summary Report of the Standing Committee on Plants, Animals, Food and Feed Held in Brussels on 05 December 2014 (Section Animal Health \& Welfare). Brussels: European Commission Health and Food Safety Directorate-general. 2014:1-7 p.

30. FGNews. Outbreak of brucellosis spreads to more than 60 farms in occupied north Cyprus. Famagusta, Cyprus; 2014.

31. Gravenor MB, Papasozomenos P, McLean AR, et al. A scrapie epidemic in Cyprus. Epidemiol Infect. 2004;132(4):751-760.

32. Touzamas P. First report of ovine scrapie in Cyprus. British Veterinary Journal. 1988;144:98-100.

33. Touzamas P. Scrapie in Cyprus. British Veterinary Journal. 1991;147:147-154.

34. Gürel A, Gülçubuk A, Turan N, et al. First report of scrapie in a sheep flock in Northern Cyprus. In: Köfer J, Schobesberger H, editors. Animal hygiene and sustainable livestock production. Proceedings of the 15th International Congress of the International Society for Animal Hygiene, Vienna, Austria, 3-7 July 2011, Volume 3. International Society for Animal Hygiene, Boxtel, The Netherlands; 2011. p. 1237-1239.

35. Gürel a, Gülçubuk a, Turan N, et al. Scrapie cases in the Northern Cyprus. Turkish Journal of Veterinary and Animal Sciences. 2013;37:311-315.

36. FGNews. Lumpy Skin Disease found in animals in north Cyprus. Famagusta, Cyprus; 2014.

37. Psyllides G. EU experts to check out LSD outbreak among cattle. Nicosia, Cyprus; 2014.

38. LGC News. Pseudo-fowl pest disease crosses border. LGC News - Online News for North Cyprus. 2013

39. Economides P. Control of zoonoses in Cyprus. Revue Scientifique Technique Office International des Epizooties. 2000;19:725-734

40. Economides P, Christophori G. Evaluation of control programmes for echinococcosis/hydatidosis in Cyprus. Rev Sci Tech. 2000;19(3):784-792. 